\title{
Education, market rigidities and growth
}

\section{Citation}

Aghion, Philippe, Philippe Askenazy, Renaud Bourlès, Gilbert Cette, and Nicolas Dromel. 2009. "Education, Market Rigidities and Growth." Economics Letters 102 (1) (January): 62-65. doi:10.1016/j.econlet.2008.11.025.

\section{Published Version}

doi:10.1016/j.econlet.2008.11.025

\section{Permanent link}

http://nrs.harvard.edu/urn-3:HUL.InstRepos:30752414

\section{Terms of Use}

This article was downloaded from Harvard University's DASH repository, and is made available under the terms and conditions applicable to Open Access Policy Articles, as set forth at http:// nrs.harvard.edu/urn-3:HUL.InstRepos:dash.current.terms-of-use\#OAP

\section{Share Your Story}

The Harvard community has made this article openly available.

Please share how this access benefits you. Submit a story.

Accessibility 


\title{
EDUCATION, MARKET RIGIDITIES AND GROWTH
}

\author{
Philippe Aghion 1, Philippe Askenazy ${ }^{2}$, Renaud Bourlès ${ }^{3}$, \\ Gilbert Cette ${ }^{4,5}$ and Nicolas Dromel ${ }^{6}{ }^{*}$
}

\footnotetext{
${ }^{1}$ Harvard

${ }^{2}$ Paris School of Economics and IZA

${ }^{3}$ Université de la Méditerranée (GREQAM)

${ }^{4}$ Banque de France (DEMS)

${ }^{5}$ Université de la Méditerranée (DEFI)

${ }^{6}$ Paris School of Economics, Université Paris 1 Panthéon-Sorbonne (CES)
}

* Corresponding author. Address correspondence to: Université Paris 1, Maison des Sciences Économiques, 106-112 boulevard de l’Hôpital, 75647 Paris cedex 13, France. Tel: +33 (0)1 44078217.

Email: nicolas.dromel@univ-paris1.fr.

NB : The views expressed in this paper are those of the authors and do not necessarily reflect the views of the institutions they belong to. 


\begin{abstract}
This paper investigates the effects of the education level, product market rigidities and employment protection legislation on growth. It exploits macro-panel data for OECD countries. For countries close to the technological frontier, education and rigidities are significantly related to TFP growth. The contribution of the interaction between product market regulation and labour market rigidity seems particularly substantial.
\end{abstract}

Keywords: Productivity; Growth; Regulations; Market Rigidities; Education

JEL codes: O47; J24; J68; L40; 057

\title{
Résumés
}

Cette étude propose une analyse empirique des effets sur la croissance du niveau d'éducation et des rigidités sur les marchés des biens et du travail. Elle mobilise pour cela des données macroéconomiques sur un panel de pays de l'OCDE. Pour les pays proches de la frontière technologique, l'éducation et les rigidités de marchés sont corrélées positivement avec la croissance de la PGF. La contribution de l'interaction entre les rigidités sur le marché des biens et les rigidités sur le marché du travail apparaît importante.

Mots clés : Productivité; croissance; régulations; rigidités de marchés; éducation

Codes JEL : O47; J24; J68; L40; 057 


\section{Introduction}

This paper contributes to the recent literature on growth determinants that emphasises the importance of the countries' positions relative to the technological frontier (see Aghion and Howitt, 2006). Education policies or regulations on product and labour markets would not have the same effects on growth, whether they are close to or far from that frontier. The hypothesis of complementarity between product and labour market regulations, in terms of their effect on growth, is also investigated.

\section{Growth and the Complementarity of Reforms}

A first strand of the related literature shows a positive effect on growth of competition and entry into the product market, particularly within highly innovating sectors (see Aghion and Griffith, 2005, for a survey). A second set of papers focuses on the relationship between job protection and growth (see Saint Paul, 1997, 2002). However, to our knowledge, previous empirical research has not yet confirmed any direct impact of job protection or of R\&D investment on growth (Bassanini and Ernst, 2002).

The model we estimate in this paper, on macro annual country panel data, aims at characterising the effect on total factor productivity (TFP) growth of the level of education in the workforce, rigidities in the product and labour markets and variations in the employment rate, in hours worked and in the capacity utilisation rate (CUR). TFP growth is measured by the variation in its $\log (\Delta \mathrm{tfp})$. Concerning the level of education in the workforce, the selected variable is the percentage of population aged 15 or over having some higher education (HIGH). This human capital stock variable can be used as a proxy for educational policies since it summarizes their history for a given country. Besides, this relatively stable variable can be of particular relevance when assessing the long-run consequences of educational policies as a driver of a country's potential growth. The synthetic indicators EPL (Employment Protection and Legislation) and PMR (Product Market Regulation), provided by the OECD, are used to characterise rigidities in the labour and product markets, respectively. The most satisfactory estimates are obtained while taking into account the interaction between these two rigidities (rather than considering them separately), and with a two-year lag on the PMR index.

To disentangle respective effects of education and rigidities, whether the country is close to or far from the technological frontier, specific variables are constructed for the two subsets of countries. For a given year, a country will be assumed close to the frontier when its structural productivity is higher than or equal to $x \%$ of the structural productivity in the United States (which display the highest structural productivity levels over the whole period). A country's structural productivity is defined as its productivity level assuming hours worked and the employment rate (whose returns are strongly decreasing) are the same as in the United States. ${ }^{7}$ This concept and its computation methods are detailed in Bourlès and Cette (2006, 2007). The frontier threshold $x$ is set at $80 \%$, which implies that $40 \%$ of the sample is close to the technological frontier. A change in this threshold does not affect the estimates significantly: if it is set at $78 \%$ ( $50 \%$ of the sample close to frontier) the conclusions barely differ.

The presence of changes in the employment rate $(\mathrm{ER})$ and hours worked $(\mathrm{H})$ variation makes it possible to take into account the decreasing returns from these two variables. The capacity utilisation rate variable corrects for cyclical effects.

Many other explanatory variables were alternatively introduced, but their estimated coefficients were not significantly different from zero. Amongst these, we can list: (i) concerning education, the percentage of population aged 15 or over with some primary or secondary education; (ii) for the labour market, the activity rates; (iii) regarding the production and innovation sectors, the share of ICT production in GDP, the ICT investment rate, the proportion of ICT in total investment, the share of private investment in total investment, the global investment volume or value, the share of public investment and the percentage of R\&D spending in GDP; (iv) as for the financial conditions, short (3 months) and long (10 years) interest

\footnotetext{
${ }^{7}$ This specification prevents from using a continuous distance to frontier index as it would imply numerous co-linearity issues about hours worked, the employment rate and productivity.
} 
rates, both nominal and real; (v) for fiscal policy, the primary public deficit, public debt and tax proceeds over GDP; (vi) for capital market regulation, stock market capitalisation to GDP, liquid liabilities to GDP, bank overhead costs as a share of total assets, bank net interest revenue as a share of interest-bearing assets and private credit granted by deposit money banks and other financial institutions over GDP.

The non-significance of ICT variables when education and rigidities are present in the model suggests that ICT investment and production, although influencing TFP growth, are strongly correlated with education and rigidities. The estimated relation can therefore be understood as a reduced-form model, in which the impact of education and rigidities on the labour and product markets are both direct and indirect, via ICT production and investment.

The estimated relation is as follows:

$$
\begin{aligned}
\Delta \mathrm{tfp} & =\mathrm{a}_{1} \cdot \mathrm{HIGH}+\mathrm{a}_{2} \cdot \mathrm{HIGH}_{\mathrm{I}_{\mathrm{x}} \%}+\mathrm{a}_{3} \cdot \text { EPL.PMR }_{-2}+\mathrm{a}_{4} \cdot \mathrm{EPL} \cdot \mathrm{PMR}_{-2} \cdot \mathrm{I}_{\mathrm{x} \%}+\mathrm{a}_{5} \cdot \Delta \mathrm{ER}+\mathrm{a}_{6} \cdot \Delta \mathrm{h} \\
& +\mathrm{a}_{7} \cdot \Delta \mathrm{CUR}+\text { intercept }+\mathrm{u}
\end{aligned}
$$

where $\mathrm{I}_{\mathrm{x} \%}$ is a dummy variable characterising the technological frontier, that equals 1 if the country's structural productivity is higher than $x \%$ of US structural productivity, and 0 otherwise.

The expected signs are: $0<a_{2} ; a_{4}<0 ;-1<a_{5} ; a_{6}<0 ; 0<a_{7}<1$. The signs of $a_{1}$ and $a_{3}$ are $a$ priori uncertain, as higher education and rigidities on the labour and product markets may as well have positive or negative effects on TFP growth far from the technological frontier (see Aghion and Howitt, 2006). Empirical analysis was carried out on a panel of 17 OECD countries during the period 1985-2003. The focus on this particular sub-sample was dictated by the limited availability (in terms of countries and years) of time series on selected variables.

The Ordinary Least Squares (OLS) estimates may be biased because of measurement errors or simultaneity issues, which can explain some counter-intuitive or unstable results. To remedy these biases, the instrumental variable method is implemented. The number of observations seems too small to apply the GMM.

Two tests are used to evaluate adjustment quality: the Sargan test (1958), which assesses the overall quality of the adjustment and relevance of the instruments, and the Davidson and Mac Kinnon test (1993) to check the exogeneity of the instruments. The list of instruments is detailed in Table 1, and the first-stage regressions estimates are available in Table 2.

\section{Main results}

The results (see Table 1) suggest that the estimated coefficient for higher education (HIGH) is systematically non-significant, while significantly different from zero (columns 6 through 8 ) with the expected positive sign when only countries close to the technological frontier are considered (HIGH.I ${ }_{80 \%}$ ). As regards the rigidities in product and labour markets, the most significant results are obtained when crossing rigidities in both markets, taking a two-year lag on the PMR index (columns 6 through 8), and separating the effects far from the technological frontier (coefficient of EPL.PMR 2 variable) from those close to the frontier (sum of coefficients of EPL.PMR -2 and EPL.PMR $2 . \mathrm{I}_{80 \%}$ variables). Other specifications for rigidities variables give estimates non-significantly different from zero. In all estimations, the coefficient of the autoregressive term is small and non-significant (column 8). However, the coefficients related to the variations in the employment rate, in hours worked and in the CUR are always significant with the expected sign and relevant in terms of economic effects.

The most relevant specification seems to be the one in column 6. It turns out that: (i) a one-point increase in the percentage of population aged 15 or over with some higher education has no impact on TFP for

\footnotetext{
${ }^{8}$ The 17 countries selected were: Australia, Austria, Belgium, Canada, Denmark, Finland, France, Germany, Ireland, Italy, Japan, the Netherlands, Portugal, Spain, Sweden, the United-Kingdom and the United States.
} 
countries far from frontier but increases TFP growth by about 0.1 point per year in countries close to technological frontier ; (ii) a one-point decrease in the product of contemporaneous EPL with two-year lagged PMR reduces TFP growth by about 0.5 point per year for countries far from the frontier, but increases TFP growth by 0.2 point per year for countries close to frontier; (iii) a one-point increase in the employment rate reduces TFP by about 0.5 ; (iv) a one-percent increase in hours worked reduces TFP by about 0.7 points ; (v) a one-point increase in the CUR (standardised over the whole sample) increases TFP by about 0.4 points.

These results are globally robust to the disaggregation of the various components of each indicator of rigidities. The detailed estimates are outlined in Aghion et al (2007). Concerning the product market, there are four components: barriers to entry, market structure, public sector size and vertical integration. The labour market indicator is broken down into employment protection and legislation on regular and temporary contracts. As for product market rigidities, the only component having no positive impact on TFP growth for countries close to the frontier appears to be the public sector size. This finding is consistent with Nicoletti and Scarpetta (2003). The two labour market rigidities components appear to have a similar impact.

\section{Conclusion}

The results presented in this paper confirm that the education level and rigidities in labour and product markets have different effects whether the country is far from or close to the technological frontier. This recalls the results synthesised in Aghion and Howitt (2006). The presented estimates are consistent with previous studies that mainly focused on product market rigidities (see for example Nicoletti and Scarpetta, 2003) but did not attempt either to characterise the crossed effect of rigidities on labour and product effects or to differentiate a specific effect close to the frontier (see Crafts 2006 for a survey). As regards the rigidities, an interaction between labour and product market regulations clearly appears; most signification results are obtained after lagging product market rigidities by two years. This confirms the results of previous analyses, as Blanchard and Giavazzi (2003). Concerning the product market regulations, the "public sector size" component appears not to have a significant effect. There is no consensus in the empirical literature on the effect of labour and product markets rigidities on growth. Numerous studies assess very disparate results: either no effect, or a positive or a negative impact (for a survey emphasising this diversity, see Babetskii and Campos, 2007). Pointing out the dependence upon the position relative to the technological frontier, our study provides an explanation for this disparity. Ignoring this heterogeneity may lead to various results depending on the countries present in the panel and their distance to the technological frontier.

The above analysis should of course be viewed with the usual caution. They rely on inevitably fragile estimates conducted on a small panel of industrialised countries. The estimates, nevertheless, suggest important gains in productivity growth, i.e. in potential growth, that may be achieved in some industrialised, mainly European, countries after undertaking ambitious reforms to increase the education level in the workforce and decrease rigidities in labour and product markets.

\section{Acknowledment}

The authors thank an anonymous referee, seminar and conference participants at various places for useful comments and suggestions. 


\section{REFERENCES}

Aghion P., Askenazy P., Bourlès R., Cette G. and Dromel N. (2007): "Education supérieure, Rigidités de marché et Croissance", CEPREMAP Working Paper, Docweb n 0705, September, www.cepremap.ens.fr

Aghion P. and Howitt P. (2006): "Joseph Schumpeter Lecture - Appropriate Growth Policy : A Unifying Framework", Journal of the European Economic Association, Vol. 4, Issue 2-3, April-May

Bassanini A. and Ernst E. (2002): "Labour Market Institutions, Product Market Regulation, and Innovation: CrossCountry Evidence”, OECD Economics Department Working Papers No. 316

Babetskii I. and Campos N. F. (2007): "Does reform work? An econometric examination of the reform-growth puzzle", CEPR, Discussion Paper Series, $n^{\circ}$ 6215, April

Blanchard O. and Giavazzi F. (2003): "Macroeconomic effects of regulation and deregulation in goods and labour markets", Quarterly Journal of Economics, August, 879-907

Bourlès R. and Cette G. (2006): “A comparison of structural productivity levels in the major industrialised countries", OECD Economic Studies, n²41 96-138

Bourlès R. and Cette G. (2007): "Trends in Structural Productivity Levels in the Major Industrialised Countries", Economic Letters vol. 95

Crafts N. (2006): "Regulation and productivity performance”, Oxford Review of Economic Policy, Vol. 22, n 2

Davidson and McKinnon (1993), "Estimation and Inference in Econometrics”, Oxford University Press, New York, 874 pages

Nicoletti G. and Scarpetta S. (2005): "Regulation and Economic Performance: Product Market Reforms and Productivity in the OECD”, OECD Economic Department Working Paper, n 460

Saint-Paul G. (1997): "Is labour rigidity harming Europe's competitiveness? The effect of job protection on the pattern of trade and welfare", European Economic Review, 41, 499-506

Saint-Paul G. (2002): "Employment protection, international specialisation and innovation", European Economic Review, 46, 375-395

Sargan J. (1958): “The Estimation of Economic Relationships Using Instrumental Variables”, Econometrica, 26 (3), 393-415 


\title{
Documents de Travail
}

229. Ph. Aghion, Ph. Askenazy, R. Bourlès, G. Cette and N. Dromel, “Education, Market Rigidities and Growth,” january 2009

Pour accéder à la liste complète des Documents de Travail publiés par la Banque de France veuillez consulter le site : http://www.banque-france.fr/fr/publications/publications.htm

For a complete list of Working Papers published by the Banque de France, please visit the website: http://www.banque-france.fr/gb/publications/publications.htm

Pour tous commentaires ou demandes sur les Documents de Travail, contacter la bibliothèque de la Direction Générale des Études et des Relations Internationales à l'adresse suivante :

For any comment or enquiries on the Working Papers, contact the library of the Directorate General Economics and International Relations at the following address :

\author{
BANQUE DE FRANCE \\ 49- 1404 Labolog \\ 75049 Paris Cedex 01 \\ tél : 0033 (0)1 42924955 ou 6265 ou 4890 ou 6981 \\ fax :0033 (0)1 42926292 \\ email : thierry.demoulin@banque-france.fr \\ jeannine.agoutin@banque-france.fr \\ veronique.jan-antuoro@banque-france.fr \\ nathalie.bataille-salle@banque-france.fr
}

